\title{
Path Modeling on the Effect of Climate Change in Nigeria
}

\author{
Chinelo Mercy Igwenagu (Ph.D) ${ }^{1,2}$ \\ ${ }^{l}$ Department of Industrial Mathematics/Applied Statistics and Demography, Enugu state University of Science \\ and Technology, Nigeria. \\ ${ }^{2}$ MERC Data Consulting Enugu, Nigeria. \\ Author Contact details: chineloigwenagu@yahoo.com, cersda2014@gmail.com. +2348063305243.
}

\begin{abstract}
Climate change is one of the environmental challenges currently facing Man, Plant and Animal existence globally. Awareness of its effect on some of the climatic factor is important; as this will tell the need for urgent abatement action, especially for developing countries who might be nonchalant given the level of their economic activities. This research therefore considered data on climatic factors collected from 18 States out of the 36 state; covering the six geopolitical zones of Nigeria. These factors were analyzed using Path analysis; with correlation coefficient as the path coefficients. The effect of climate change on these factors was measured by the path coefficients obtained from the correlation analysis. Path modeling shows the order in which these factors are affected. The regression result shows some effect of multicolinearity among the variables used. However the $R^{2}$ value of 0.668 indicates that the variables used accounted for $66.8 \%$ approximately $67 \%$ of the total variability in the values of the response variable; that is accounted for by the fitted regression model. Therefore the model can be said to have a good fit, hence the variables were used for Path modeling.
\end{abstract}

Keywords: Climate change, Effects, Factors, Global warming, Path Analysis.

\section{INTRODUCTION}

Global warming is anthropogenic, and when it occurs, it's dangerous consequences include climate change which is caused by change in climatic factors such as rainfall, temperature, wind current, relative humidity e.t.c. The increasing global consensus built on empirical evidence that the world is facing a threat from climate change has sustained the feeling and belief that many countries in tropical and sub-tropical regions are more vulnerable to the bizarre phenomenon. [1]. Nigeria is believed to be among these regions and as such should be interested in any abatement action with the knowledge that increase in global warming and climate change could lead to the extinction of one-fourth of Earth's species by 2050[2]. The effect of climate change is already being experience around the globe; seasons are shifting from what obtains in the past, this can be witnessed by the current pattern of rainfall, rise in the sea level, rising temperature, melting of the polar ice cap and change in agricultural yields. These changes pose serious threat to human lives, to economic development and to the natural world on which much of our prosperity depends. Society therefore needs to take measures to adapt to these unavoidable impacts while taking action to cut the greenhouse gas emissions that are almost certainly causing climate change. [3].This study therefore is interested in establishing a possible model which shows the effect of global warming on climate change, based on the coefficients obtained from the climatic factors considered. This will help in taking the issue of climate change serious in Nigeria. In view of this, this study employed the technique of Path analysis as a tool for modeling the effect of climate change. The technique is used to describe the direct dependencies among a set of variables. Its model is equivalent to any form of multiple regression analysis, factor analysis, correlation analysis as well as more general families of models in the multivariate analysis of variance and covariance analyses [4]. Path analysis could also be referred to as a statistical technique used primarily to examine the comparative strength of direct and indirect effects on variables; this is achieved by solving one or more structural Equations, to estimate a series of parameters in order to test the fit of the correlation matrix between two or more causal models hypothesized by the researcher to fit the data. Therefore this study considered this tool appropriate for examining the effect of climate change in Nigeria based on data available on some climatic factors.

\section{METHODOLOGY}

Nigeria is made up of thirty -six states, in this study, out of the thirty -six states, data on factors such as temperatures, evaporation pitch, rainfall, relative humidity, solar radiation, and wind current were collected for a period of 17 years (1991-2007), from eighteen states were data are available These factors are considered to be affected by global warming which causes climate change. Though data were available on only eighteen States, but careful examination reveals that all the geopolitical zones were fully represented, hence the data could be 
used for estimating the country's position. TABLE 1 below shows the data on $\mathrm{CO}_{2}$ emission and other possible correlates in Nigeria which will be used for analysis.

Table $1 \mathrm{CO}_{2}$ emission and some climatic factors in Nigeria.

$\begin{array}{lccccccc}\text { yr/Var. } & \operatorname{Tmax}\left({ }^{\circ} \mathrm{c}\right) & \mathrm{RF}(\mathrm{mm}) & \mathrm{RH}(\%) & \mathrm{Rad}(\mathrm{ml}) & \mathrm{Eva}(\mathrm{ml}) & \mathrm{W} / \mathrm{C}(\mathrm{m} / \mathrm{s}) & \begin{array}{l}\mathrm{CO}_{2} \\ \text { (tons) }\end{array} \\ & & & & & & & \\ 1991 & 323.98 & 1403.04 & 697.84 & 285.17 & 65.82 & 58.05 & 0.50 \\ 1992 & 318.54 & 1358.72 & 668.89 & 289.61 & 71.47 & 58.88 & 0.10 \\ 1993 & 323.77 & 1347.34 & 669.89 & 295.28 & 69.38 & 59.73 & 0.70 \\ 1994 & 322.51 & 1373.11 & 681.33 & 291.67 & 69.59 & 59.26 & 0.60 \\ 1995 & 324.41 & 1438.76 & 676.84 & 295.18 & 72.66 & 59.27 & 0.50 \\ 1996 & 323.35 & 1508.38 & 696.84 & 296.39 & 67.96 & 56.68 & 0.30 \\ 1997 & 332.01 & 1441.78 & 697.39 & 288.58 & 66.29 & 56.75 & 0.40 \\ 1998 & 338.77 & 1373.41 & 693.72 & 287.71 & 74.33 & 58.372 & 0.40 \\ 1999 & 324.49 & 1607.77 & 797.44 & 279.88 & 69.98 & 54.344 & 0.40 \\ 2000 & 323.47 & 1317.47 & 684.11 & 288.56 & 74.63 & 55.53 & 0.40 \\ 2001 & 324.72 & 1390.17 & 681.53 & 294.08 & 70.37 & 56.69 & 0.40 \\ 2002 & 326.47 & 1394.92 & 678.56 & 293.32 & 68.55 & 56.26 & 0.40 \\ 2003 & 328.64 & 1412.79 & 689.33 & 288.79 & 67.12 & 60.92 & 0.40 \\ 2004 & 328.58 & 1371.07 & 685.09 & 282.544 & 71.80 & 58.54 & 0.42 \\ 2005 & 330.34 & 1362.52 & 684.28 & 288.28 & 67.73 & 58.52 & 0.83 \\ 2006 & 325.27 & 1429.14 & 683.17 & 288.99 & 68.82 & 60.46 & 0.82 \\ 2007 & 326.87 & 1457.27 & 679.72 & 297.94 & 69.41 & 62.39 & 0.83\end{array}$

Source: Calculated from data from Metrological service department Headquarter at Oshodi Lagos State, Nigeria.

In Path modeling, either regression coefficient or correlation coefficient could be used; therefore this study uses the correlation coefficient obtained from the correlation analysis. Correlation analysis was carried out to determine which of these factors have correlation with $\mathrm{CO}_{2}$ emission and the strength of their relationship determines the extent of effect of climate change on these factors. The correlation analysis result is as presented on TABLE 2 below.

Table 2 Correlation Analysis of $\mathrm{CO}_{2}$ Emission with Respect to Some Possible climatic factors.

\begin{tabular}{|c|c|c|c|c|c|c|c|c|}
\hline & & $\begin{array}{l}\text { Temperatur } \\
\mathrm{e}\end{array}$ & Rainfall & $\begin{array}{l}\text { Relative } \\
\text { Humidity }\end{array}$ & $\begin{array}{c}\text { Solar } \\
\text { Radiation }\end{array}$ & $\begin{array}{c}\text { Evaporatio } \\
\text { n Pitch }\end{array}$ & $\begin{array}{c}\text { Wind } \\
\text { Current }\end{array}$ & $\begin{array}{l}\mathrm{CO}_{2} \\
\text { Emission }\end{array}$ \\
\hline \multirow{3}{*}{$\begin{array}{l}\text { Temperatur } \\
\mathrm{e}\end{array}$} & Pearson Correlation & 1 & -.048 & .059 & -.212 & .055 & .058 & .162 \\
\hline & Sig. (2-tailed) & & .854 & .823 & .415 & .835 & .825 & .534 \\
\hline & $\mathrm{N}$ & 17 & 17 & 17 & 17 & 17 & 17 & 17 \\
\hline \multirow[t]{3}{*}{ Rainfall } & Pearson Correlation & -.048 & 1 & $.789(* *)$ & -.148 & -.294 & -.255 & -.059 \\
\hline & Sig. (2-tailed) & .854 & & .000 & .570 & .252 & .323 & .823 \\
\hline & $\mathrm{N}$ & 17 & 17 & 17 & 17 & 17 & 17 & 17 \\
\hline \multirow[t]{3}{*}{$\begin{array}{l}\text { Relative } \\
\text { Humidity }\end{array}$} & Pearson Correlation & .059 & $.789(* *)$ & 1 & $-.608(* *)$ & -.085 & $-.547(*)$ & -.151 \\
\hline & Sig. (2-tailed) & .823 & .000 & & .010 & .746 & .023 & .562 \\
\hline & $\mathrm{N}$ & 17 & 17 & 17 & 17 & 17 & 17 & 17 \\
\hline \multirow[t]{3}{*}{$\begin{array}{l}\text { Solar } \\
\text { Radiation }\end{array}$} & Pearson Correlation & -.212 & -.148 & $-.608(* *)$ & 1 & -.035 & .387 & .212 \\
\hline & Sig. (2-tailed) & .415 & .570 & .010 & & .894 & .125 & .414 \\
\hline & $\mathrm{N}$ & 17 & 17 & 17 & 17 & 17 & 17 & 17 \\
\hline \multirow[t]{3}{*}{$\begin{array}{l}\text { Evaporation } \\
\text { Pitch }\end{array}$} & Pearson Correlation & .055 & -.294 & -.085 & -.035 & 1 & -.124 & -.238 \\
\hline & Sig. (2-tailed) & .835 & .252 & .746 & .894 & & .634 & .357 \\
\hline & $\mathrm{N}$ & 17 & 17 & 17 & 17 & 17 & 17 & 17 \\
\hline \multirow[t]{3}{*}{$\begin{array}{l}\text { Wind } \\
\text { Current }\end{array}$} & Pearson Correlation & .058 & -.255 & $-.547(*)$ & .387 & -.124 & 1 & $.527(*)$ \\
\hline & Sig. (2-tailed) & .825 & .323 & .023 & .125 & .634 & & .030 \\
\hline & $\mathrm{N}$ & 17 & 17 & 17 & 17 & 17 & 17 & 17 \\
\hline
\end{tabular}




\begin{tabular}{|c|c|c|c|c|c|c|c|c|}
\hline $\mathrm{CO}_{2}$ & Pearson Correlation & .162 & -.059 & -.151 & .212 & -.238 & $.527(*)$ & 1 \\
\hline Emission & Sig. (2-tailed) & .534 & .823 & .562 & .414 & .357 & .030 & \\
\hline & $\mathrm{N}$ & 17 & 17 & 17 & 17 & 17 & 17 & 17 \\
\hline
\end{tabular}

** Correlation is significant at the 0.01 level (2-tailed).

* Correlation is significant at the 0.05 level (2-tailed).

The result of the correlation analysis, shown in TABLE 2 above indicates that there is positive correlation between $\mathrm{CO}_{2}$ emission and factors like Temperature, solar radiation and wind current. However, negative correlation exists between $\mathrm{CO}_{2}$ emission rainfall, relative humidity and evaporation pitch. Wind current show a significant effect with $\mathrm{P}$-value $=0.030$. Further examination reveals that there exists a significant correlation among some possible factors. For instance, there is significant correlation between Rainfall and Relative humidity with P-value of 0.000; between Relative humidity and Solar radiation with p-value of 0.010; between wind current and relative humidity with p-value of 0.023 . Hence the following expression can be used to express the relationship between $\mathrm{CO}_{2}$ emission and the selected factors;

$: \mathrm{CO}_{2}$ emission $=\mathrm{F}$ (Temperature, Solar radiation and Wind current)

\section{(Effect of climate change)}

Since Path modeling uses both correlation and regression coefficients in modeling, regression analysis can also be considered. Using the Statistical Package for Social Sciences (SPSS), the result obtained is as shown in the TABLE 3 below:

Table 3 Regression Analysis of $\mathrm{CO}_{2}$ Emission with Respect to Some Possible climatic factors

Model Summary

\begin{tabular}{|c|c|c|c|c|c|c|c|c|c|c|}
\hline Model & $\mathrm{R}$ & $\begin{array}{c}\mathrm{R} \\
\text { Square }\end{array}$ & $\begin{array}{l}\text { Adjusted } \\
\text { R Square }\end{array}$ & $\begin{array}{l}\text { Std. Error } \\
\text { of the } \\
\text { Estimate }\end{array}$ & \multicolumn{5}{|c|}{ Change Statistics } & $\begin{array}{l}\text { Durbin- } \\
\text { Watson }\end{array}$ \\
\hline & $\begin{array}{l}\text { R Square } \\
\text { Change }\end{array}$ & $\begin{array}{c}\mathrm{F} \\
\text { Change }\end{array}$ & df1 & df 2 & $\begin{array}{c}\text { Sig. F } \\
\text { Change }\end{array}$ & $\begin{array}{c}\text { R Square } \\
\text { Change }\end{array}$ & $\begin{array}{c}\mathrm{F} \\
\text { Change }\end{array}$ & df1 & $\mathrm{df} 2$ & $\begin{array}{c}\text { Sig. F } \\
\text { Change }\end{array}$ \\
\hline 1 & $.668(a)$ & .446 & .113 & .18919 & .446 & 1.341 & 6 & 10 & .324 & 1.546 \\
\hline
\end{tabular}

a Predictors: (Constant), Wind Current, Temperature, Evaporation Pitch, Rainfall, Solar Radiation, and Relative Humidity

b Dependent Variable: $\mathrm{CO}_{2}$ emission

ANOVA

\begin{tabular}{|ll|r|r|r|r|r|}
\hline Model & & Sum of Squares & \multicolumn{1}{c|}{ df } & Mean Square & F & Sig. \\
\hline 1 & Regression & .288 & 6 & .048 & 1.341 & $.324(\mathrm{a})$ \\
& Residual & .358 & 10 & .036 & & \\
& Total & .646 & 16 & & & \\
\hline
\end{tabular}

a Predictors: (Constant), Wind Current, Temperature, Evaporation Pitch, Rainfall, Solar Radiation, and Relative Humidity

b Dependent Variable: $\mathrm{CO}_{2}$ emission

Coefficients (a)

\begin{tabular}{|c|c|c|c|c|c|c|}
\hline \multirow{2}{*}{\multicolumn{2}{|c|}{ Model }} & \multicolumn{2}{|c|}{$\begin{array}{l}\text { Unstandardized } \\
\text { Coefficients }\end{array}$} & \multirow{2}{*}{$\begin{array}{c}\text { Standardized } \\
\text { Coefficients } \\
\text { Beta }\end{array}$} & \multirow{2}{*}{$\begin{array}{l}\mathrm{t} \\
\mathrm{B}\end{array}$} & \multirow{2}{*}{$\begin{array}{c}\text { Sig. } \\
\text { Std. Error }\end{array}$} \\
\hline & & B & Std. Error & & & \\
\hline \multirow[t]{4}{*}{1} & (Constant) & -12.880 & 8.140 & & -1.582 & .145 \\
\hline & Temp & .007 & .011 & .147 & .600 & .562 \\
\hline & Rainfall & -.002 & .002 & -.769 & -1.254 & .238 \\
\hline & RelHum & .008 & .006 & 1.137 & 1.435 & .182 \\
\hline
\end{tabular}




\begin{tabular}{l|r|r|r|r|r|}
\hline Rad & .022 & .018 & .540 & 1.261 \\
Evap & -.021 & .020 & -.269 & -1.033 \\
WC & .069 & .030 & .703 & 2.260 \\
.326 \\
\hline
\end{tabular}

a Dependent Variable: $\mathrm{CO}_{2}$ emission

The regression model can be expressed thus:

$$
: C O_{2}=b_{0}+b_{1} T-b_{2} \mathrm{R}+b_{3} \mathrm{H}+b_{4} \mathrm{~S}-b_{5} \mathrm{E}+b_{6} \mathrm{~W}
$$

Substituting the parameters of the model with the estimated values, equation (2) becomes

$$
: \mathrm{CO}_{2}=-12.880+0.007 \mathrm{~T}-0.002 \mathrm{R}+0.008 \mathrm{H}+0.022 \mathrm{~S}-0.021 \mathrm{E}+0.069 \mathrm{~W}
$$

Where

$\mathrm{T}=$ Temperature, $\mathrm{R}=$ Rainfall, $\mathrm{H}=$ Relative humidity, $\mathrm{S}=$ Solar radiation, $\mathrm{E}=$ Evaporation Pitch, $\mathrm{W}=$ Wind current

From (1) and (2) above, we can simply say that there is a linear relationship between $\mathrm{CO}_{2}$ emission and selected climate factors; from these equations, effects of $\mathrm{CO}_{2}$ emission can be estimated and the level of climate change also estimated.

Careful observation reveals that the data are not of the same unit therefore may require centering or standardization. If two independent variables are measured in exactly the same units, it is usually preferable since the relative importance of their respective effects on y we can be assessed easily; knowing that the larger the coefficient, the stronger the effect [5]. However, our explanatory variables are not all measured in the same units, hence their relative importance becomes difficult to assess. However, to overcome this problem, we either standardize or center these variables. We can generalize standardization to include sets of variables, thus incorporating factors, interactions, and multiple. This is similar but not the same with centering. In centering, the values of the variables are changed but not the scale. Meanwhile, a predictor that is centered at the mean has new values and the entire scales are shifted, so that the mean will have a value of 0 , but one unit is still one unit. The intercept will change, but the regression coefficient for that variable will not. Since the regression coefficient is interpreted as the effect on the mean of $\mathrm{Y}$ for each one unit difference in $\mathrm{X}$, it does not change when $X$ is centered. [6]. The same assumption is also extended to this study from (2); thus:

Suppose the independent variables $X_{1}, X_{2}, X_{3}, \ldots X_{k}$ are standardized as follows, $X_{i j}$, is transformed into $X_{i j}^{S}$ using

Where

$$
: \quad X_{i j}^{S}=\frac{X_{i j}-X_{i j}}{s_{x j}}
$$

$S_{x j}=$ the standard deviation of the independent variable $X_{j}$ Superscript s indicates that the independent variables are standardized

The process of standardization of the independent variables allows for the alternative formulation of equation (2)

$$
: y_{i}=B_{0}^{s}+B_{1}^{s}\left[\frac{x_{1 i}-\bar{x}_{1}}{s_{x_{1}}}\right]+B_{2}^{s}\left[\frac{X_{2 i}-X_{2}}{s_{x_{2}}}\right]+\ldots+B_{k}^{S}\left[\frac{x_{k i}-\overline{X_{k}}}{s_{x_{2}}}\right]+\varepsilon_{i}
$$

Let $b^{s}=\left(b_{1}^{S}, b_{1}^{S}, \ldots, b_{1}^{s}\right)$ be the least square estimators of $B^{s}$. If a data set is used to fit the standardized model in (4), then the estimates of the coefficients of the model of (2) can be obtained from the estimates of coefficients for the standardized variables using the following transformation:

$$
: b_{j}=\left[\frac{b_{j}}{s_{x_{1}}}\right] \mathrm{j}=1,2, \ldots, \mathrm{k}
$$

And 


$$
: b_{0}=b_{0}-\left[\frac{b_{1 \bar{X} 1}^{s}}{s_{x_{1}}}\right]-\left[\frac{b_{2 \bar{X} 2}^{s}}{s_{x_{2}}}\right]-\ldots-\left[\frac{b_{1 k \bar{X} k}^{s}}{s_{x_{k}}}\right]
$$

It is always possible to move from one model formulation to another regardless of which model was used for analysis [7]. In view of this, the path modeling will be based on the correlation coefficients on TABLE 2 above. However, the Path model for the effect of climate change in Nigeria will be based on only the factors that show significant relationship based on the correlation matrix of table 2 above. Therefore, Path model using the selected model is as shown below

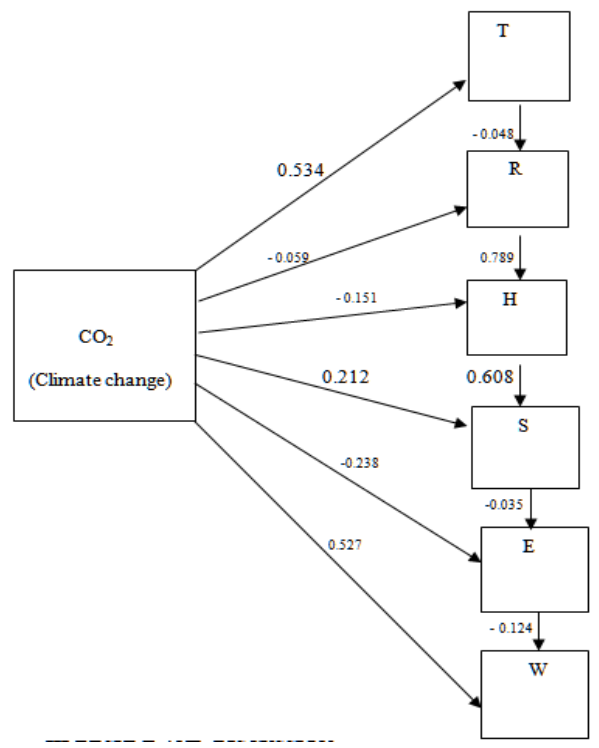

\section{Result And Discussion}

The correlation coefficient of direct and indirect path coefficients determines the relationship between possible factors and $\mathrm{CO}_{2}$ emission, the result based on the effect of climate change on the selected factors indicates that $53.4 \%,-5.9 \%$, $15.1 \%, 21.2 \%,-23.8 \%$ and $52.7 \%$ respectively were due to direct effect, while $4.8 \%, 78.9 \%, 60.8 \%,-3.5 \%$ and $-12.4 \%$ respectively were due to indirect effect of $\mathrm{CO}_{2}$ emission on the selected factors. This implies that $\mathrm{CO}_{2}$ emission has $53.4 \%$ direct effect on the temperature 5.9\% direct negative effect on Rainfall, $15.1 \%$ direct effect on relative humidity, $21.2 \%$ direct effect on solar radiation, $23.8 \%$ direct negative effect on evaporation pitch and $52.7 \%$ direct effect on wind current. Its various indirect effects are as follows; $4.8 \%$ indirect negative effect through temperature, $4.9 \%, 78.9 \%$ indirect effect through Rainfall, 60.8\% indirect effect through relative humidity, 3.5 indirect negative effect through solar radiation and $12.4 \%$ indirect effect through evaporation pitch. Rainfall and Relative humidity are highly significant based on the analysis result; hence the indirect effect through rainfall to relative humidity is high about $78.9 \%$. This could explain the recent changes being experienced in the pattern of rainfall in some part of the country. The regression analysis result shows that the variables used accounted for $66.8 \%$ approximately $67 \%$ of the total variability in the values of the response variable; that is accounted for by the fitted regression model. Therefore the model can be said to have a good fit..

\section{Conclusion}

This study agrees that the effect of Climate change is more on temperature; with $53.4 \%$ direct effect. The effect on rainfall based on this study is minimal; yet recent observation shows a change in pattern of rainfall. Meanwhile, there is noticeable effect of multicolinearity in the model; given the negative coefficients, but the study does not intend to look at the best model rather interest is just in modeling the effect on the selected variables using Path analysis technique. Therefore, further study should use the technique of model selection to select the variables with the best model.

\section{References}

[1] I.N Nwachukwu, C.I Ezeh and C.O Emerole, The effect of Climate Change on Cocoa Production in Nigeria. African Crop Science Journal, Vol. 20(2012) 487 - 491

[2] Global Warming and Climate Change Threats and Impacts http://www.nature.org/ourinitiatives/urgentissues/global-warming-climatechange/threats-impacts/ Acessed April 25, 2014

[3]. Consequences of climate change. http://ec.europa.eu/clima/policies/brief/consequences/index_en.htm Acessed April 25, 2014.

[4]. C. Lleras, Path Analysis. Encyclopedia of Social measurement vol 3 Assessed 23th April, 2014

[5] G. J. William, Standardizing and Relative Importance. Regression III: Advanced Methods http://polisci.msu.edu/jacoby/icpsr/regress3 Accesses $9^{\text {th }}$, May, 2014

[6]. Karen, Centering and Standardizing Predictors. http://www.theanalysisfactor.com/centering-and-standardizing-predictors/ Accesses $9^{\text {th }}$, May, 2014

[7]. C.M Igwenagu, Statistical Modeling of Global Warming. Journal of Modern Mathematics and Statistics 7(4): (2013) ISSN: 1994-5388 Medwell Journals, 41-46 